\title{
Phenotypic and Enzymatic Analyses of Upland Rice Lines Seeds under No-Tillage
}

\author{
Heloisa Oliveira dos Santos, Flávia Barbosa Silva Botelho, Ricardo Kenji Uenojo, \\ Ana Cláudia de Amorim Fonseca, Marcela Pedroso Mendes*, \\ Edila Vilela de Resende Von Pinho, Maria Laene Moreira de Carvalho \\ Department of Agriculture, Federal University of Lavras, Lavras, Brazil \\ Email: heloisasantos@dag.ufla.br, flaviabotelho@dag.ufla.br, ricardokenji92@gmail.com, \\ ana.c.amorim@gmail.com, celapmendes@gmail.com, edila@dag.ufla.br, mlaenemc@dag.ufla.br
}

Received 16 June 2015; accepted 18 August 2015; published 21 August 2015

Copyright (C) 2015 by authors and Scientific Research Publishing Inc.

This work is licensed under the Creative Commons Attribution International License (CC BY). http://creativecommons.org/licenses/by/4.0/

cC) (7) Open Access

\section{Abstract}

Over $40 \%$ of the agricultural area in Brazil corresponds to no-tillage farming. Although it is evident the importance of obtaining upland rice cultivars adapted to this cropping system, researches in this sense are still incipient and breeders do not have cultivars available to recommend with enough security. The aim of this study was to evaluate phenotypic characters favorable to the no-tillage system in order to establish the basis for upland rice breeding programs interested in this cropping system. The seeds of twenty elite inbred lines from the Upland Rice Breeding Program from the Brazilian research institutions UFLA, EMBRAPA and EPAMIG were evaluated at the Central Seeds Lab from the Agriculture Department of UFLA following a randomized block design with four replicates. The characters evaluated were seedlings emergence (SE), green matter yield (GM), dry matter yield (DM), photosynthetic activity (PA), and superoxide dismutase activity (SOD). The quality parameters evaluated were obtained by a germination test (GT), germination first count (GFC), emergence test (E), initial stand (IS), and alpha-amylase expression. The lines CMG 2074, CMG 1967, CMG 2017, BRSMG Caravera and CMG 2097 showed higher SOD content in the enzymatic analyses, and consequently higher tolerance to abiotic stresses that could be caused by no-tillage. Considering the evaluation of agronomic traits, the line CMG 1967 showed the best performance in no-tillage soil and, therefore, should receive higher attention in Upland Rice Breeding Programs.

\section{Keywords}

Oriza sativa, Physiologic Quality, Enzymatic Expression, Cropping System, Vigor

\footnotetext{
*Corresponding author.
} 


\section{Introduction}

Rice (Oryza sativa L.) is among of the most consumed cereals in the world, and is the main source of carbohydrates in Brazil [1]. The rice production in Brazil reached nearly 12,400 millions of tons in 2344 hectares in the 2014/2015 growing season, and the main producer states were Rio Grande do Sul, Santa Catarina and Maranhão, responsible for $70 \%$ of the production [2].

Although Brazilian production is mainly of irrigated rice, Brazil has the biggest cultivated area of upland rice in the world, mostly in the states of Mato Grosso, Tocantins and Maranhão [2]. In these regions, rice is cultivated by small farmers without any irrigation, in acid soil, poor of nutrients, low water retention and with irregular rain precipitation [3].

Since the $80 \mathrm{~s}$, much of the upland rice has been cultivated in order to start new farmable fields in degraded pastures and deforested areas [2]. Although this strategy has increased the cultivated area, the cultivation of upland rice should not be considered only in this situation, because it does not supply internal demand. In this context, the obtaining of upland rice cultivars adapted to no-tillage system enables rotation with other crops, supplies the rice demand and guarantees another alternative for small farmers.

Besides allowing crop rotation, the usage of no-till system improves soil fertility, erosion protection, infiltration, and water availability, minimizing environmental impacts. However, the successful implementation of this system directly depends on the biomass production in rotation systems, without which the objectives and advantages of this type of cultivation will not be the same [4].

According to the Brazilian Federation of No-Tillage and Irrigation Systems (FEBRAPDP), the area with notillage in Brazil has nearly 30 millions of hectares, reinforcing the importance of obtaining upland rice cultivars adapted to this system. Furthermore, rice has a high biomass production that benefits crop rotation. However, the use of upland rice in no-tillage system is not successful. The initial growth and development of the rice seedlings are affected, probably because of the transformation of nitrate, predominant in no-tillage system, in ammonium, which is absorbed and hampers seedling development [5].

Nevertheless, the consolidation of this cropping system is essential to enable rice cultivation in regions where only no-tillage is used, especially because rice production using irrigated systems is reaching the edge. The obtainment of new upland rice cultivars adapted to no-tillage system is the best alternative to supply the increasing demand of rice. The aim of this study was to evaluate upland rice lines for phenotypic characters favorable to the no-tillage system in order to establish the basis for upland rice breeding programs interested in this cropping system.

\section{Material and Methods}

The seeds of twenty elite inbred lines from the Upland Rice Breeding Program from the Brazilian research institutions UFLA, EMBRAPA and EPAMIG were evaluated at a greenhouse in the Central Seeds Lab from the Agriculture Department of UFLA following a randomized block design with four replicates. Each plot was a 3L plastic pot with four plants sowed in soil from a no-tillage area prepared as recommended for rice crop. The characters evaluated were:

1) Seedling emergence, as the number of days from sowing and the emergence of $50 \%$ of the plants from each plot;

2) Green matter yield, as the weight of green matter of one plant from each plot;

3) Dry matter yield, as the weight of the same sample used to determinate the green matter stored in warm house for $72 \mathrm{~h}$ in $65^{\circ} \mathrm{C}$ and $0 \%$ of humidity;

4) Photosynthetic activity, as therelative chlorophyll index (RCI) measured by a chlorophyll meter (SPAD), obtained as the mean of 30 reedsin five leaves;

5) Superoxide dismutase (SOD) activity, obtained by spectrophotometry. Leaves from each genotype were smashed using liquid nitrogen. Then, $0.2 \mathrm{~mL}$ of acetone $80 \%$ was added to $0.1 \mathrm{~g}$ of each sample, mixed for 5 minutes. The samples were centrifuged in $6.000 \mathrm{rpm}$ for 10 minutes and the supernatant discarded. For the enzymes extraction, it was used $0.2 \mathrm{~mL}$ of the extraction buffer Tris $40 \mathrm{mM}$ (pH 7.8) containing Manitol 350 mM, EDTA $2 \mathrm{mM}$ and PVP 3\%. The samples were centrifuged in $10.000 \mathrm{rpm}$ for 20 minutes in $4^{\circ} \mathrm{C}$. The supernatant were stored in chamber at $-20^{\circ} \mathrm{C}$. Then, $0.1 \mathrm{~mL}$ of each sample were put in test tubes protected of light with a potassium phosphate buffer $(50 \mathrm{mM}, \mathrm{pH} 7.8$, EDTA $0.1 \mathrm{mM}$, L-methionine $13 \mathrm{mM}$ and NBT $75 \mu \mathrm{M})$. The reaction was initiated adding Riboflavin $6 \mu \mathrm{M}$ and transferring the tubes to a lighted chamber 
for 15 minutes. The reeds were made using spectrophotometry (Spectronic 20 Genesys) and the SOD activity was determined calculating the quantity of extract that inhibited $50 \%$ of the NBT [6].

Biochemical and physiological analyses were also performed using seeds from each line treated with the commercial fungicide Vitavax-Thiram ${ }^{\mathbb{Q}}, 0.003 \mathrm{~L}$ by kilogram of seed. The tests performed were:

1) Germination test, using 50 seeds of each inbred line with four replicates, distributed on Germitest ${ }^{\mathbb{B}}$ paper moistened with water amount equivalent to 2.5 times the mass of dry substrate, and maintained in germination chamber at $25^{\circ} \mathrm{C}$ degrees. Two counts of the number of normal seedlings were performed at the fifth and fourteenth days after sowing, according to recommendation in Brasil [7]. The results were expressed as the average percentage of normal seedlings from the four replicates;

2) Germination first count, performed together with the germination test, considering a seedling as normal when showing $0.5 \mathrm{~cm}$ of shoot length and $2.5 \mathrm{~cm}$ of root length at the fifth day after sowing;

3) Emergence in plat, evaluated sowing four replicates of 50 seeds from each line in a $1 \mathrm{~m} \mathrm{x} 4 \mathrm{~m}$ plat with the lines arranged randomly. Daily assessments were performed from the first day of seedlings emergency until the stabilization of the stand. The results were expressed as the percentage of normal emerged seedlings at the seventh and tenth days after sowing;

4) Initial stand, as the percentage of normal emerged seedlings at the twenty-first day after sowing;

5) Alpha-amylase expression, inferred considering the intensity of bands of electrophoretic analysis in a transilluminator. Two samples of 25 seeds from each line were soaked with water for 72 hours and then smashed using PVP (Polyvinylpolypyrrolidone) and liquid nitrogen. For the enzymes extraction, it was used an extraction buffer (Tris $\mathrm{HCl} 10.2 \mathrm{M} \mathrm{pH} 8+0.1 \%$ of $\beta$-mercaptoetanol) in the proportion of $250 \mu \mathrm{L}$ by $100 \mathrm{mg}$ of sample. The samples were homogenized in vortex and maintained in fridge during the night. They were centrifuged in $14.000 \mathrm{rpm}$ for 30 minutes in $4^{\mathrm{O}} \mathrm{C}$ degrees, and $60 \mu \mathrm{L}$ of the sample were added to a polyacrylamide gel ( $7.5 \%$ of separator gel and $4.5 \%$ of concentrator gel) to perform electrophoretic analysis (150 Volts for 5 hours) using the gel/electrode system Tris-glycine $\mathrm{pH}$ 8.9.

Analyses of variance were performed with the data from each character using the statistical software SISVAR [8], and the means compared according to the Scott-Knott approach [9] with 5\% of probability. The evaluation of enzymatic patters were performed according to the intensity if the bands [10].

\section{Results and Discussion}

Highly coefficients of variation (CV\%) were observed for all characters, indicating that the experiments were carried out with high precision (Garcia, 1989). Significant differences $(p \leq 0.05)$ between rice lines were detected in the analyses of variance for seedlings emergency and green matter yield. However, for green matter, only the line CMG1967 showed superiority. For the characters dry matter yield and photosynthetic intensity, the lines did not differ statistically (Table 1).

Green matter and dry matter yield are directly correlated to the photosynthetic rate and consequently the production of photoassimilates by plants [11]. Similar to this study, no variability for dry matter yield was found in millet genotypes [12]. However, variability for this character was found in sugar cane [13] and lettuce [14]. For green matter, variability was found between genotypes of lettuce [14], irrigated rice [15] and guava [16].

The speed of seedlings emergency is very important in the context of competition with weeds at the initial crop development, as the higher the speed of emergence, the better the chances of reducing competition effect [17]. Seventeen of the twenty lines had good results for this character. Only the lines CMG 2173, CMG 1097-7 and BRS Caravera showed a bad performance and were considered less vigorous. Variability in the speed of emergency was also found in irrigated rice [18] and sugar cane [19] genotypes.

Photosynthetic activity is measured by the content of chlorophyll in the leaves and consequently is correlated with the content of nitrogen, since this nutrient is part of the chlorophyll molecule. Thereby, the photosynthetic activity can be considered an indirect, instantaneous and non-destructive way to estimate the nutritional state of the genotypes in what regards to the $\mathrm{N}$ content, and can be used to indicate the need of nitrogen fertilization in any stage of crop development [20].

Lopes et al. [21] and Argenta et al. [22] showed positive correlations between the rate of total chlorophyll and the content of $\mathrm{N}$ in the leaf $(\mathrm{r}=0.81$ and $\mathrm{r}=0.59)$. In this study, all twenty lines showed good estimates of the photosynthetic activity, but they did not differed significantly.

According to Takabe and Yoneyama [23], most of rice genotypes do not have a significant quantity of nitrate, 
Table 1. Means of days to seedlings emergence (SE), green matter yield (GM), dry matter yield (DM) and photosynthetic intensity (PI) of the twenty upland rice lines and their coefficient of variation (CV).

\begin{tabular}{|c|c|c|c|c|}
\hline Lines & SE (days) ${ }^{*}$ & $\mathrm{GM}(\mathrm{g})^{*}$ & $\mathrm{DM}(\mathrm{g})^{*}$ & PA (IRC, SPAD) ${ }^{*}$ \\
\hline BRSMG Curinga & $7.0 \mathrm{a}$ & $12.57 \mathrm{~b}$ & $5.46 \mathrm{a}$ & $42.82 \mathrm{a}$ \\
\hline CMG 1967 & $8.0 \mathrm{a}$ & $15.32 \mathrm{a}$ & $6.06 \mathrm{a}$ & $37.60 \mathrm{a}$ \\
\hline BRS Esmeralda & $8.0 \mathrm{a}$ & $10.70 \mathrm{~b}$ & $4.98 \mathrm{a}$ & $44.30 \mathrm{a}$ \\
\hline CMG 2170 & $7.0 \mathrm{a}$ & $12.13 \mathrm{~b}$ & $5.26 \mathrm{a}$ & $33.52 \mathrm{a}$ \\
\hline CMG 2173 & $9.0 \mathrm{~b}$ & $11.30 \mathrm{~b}$ & $5.03 \mathrm{a}$ & $36.35 \mathrm{a}$ \\
\hline BRSMG Caçula & $7.0 \mathrm{a}$ & $14.12 \mathrm{~b}$ & $5.71 \mathrm{a}$ & $35.15 \mathrm{a}$ \\
\hline CMG 1097-7 & $9.0 \mathrm{~b}$ & $13.20 \mathrm{~b}$ & $5.76 \mathrm{a}$ & $39.90 \mathrm{a}$ \\
\hline CMG 2074 & $8.0 \mathrm{a}$ & $10.95 \mathrm{~b}$ & $4.98 \mathrm{a}$ & $35.25 \mathrm{a}$ \\
\hline CMG 1698 & $7.0 \mathrm{a}$ & $13.65 \mathrm{~b}$ & $5.56 \mathrm{a}$ & $41.32 \mathrm{a}$ \\
\hline CMG 2085 & $8.0 \mathrm{a}$ & $9.80 \mathrm{~b}$ & $4.73 \mathrm{a}$ & $33.50 \mathrm{a}$ \\
\hline BRSMG Caravera & $9.0 \mathrm{~b}$ & $9.15 \mathrm{~b}$ & $4.46 \mathrm{a}$ & $35.75 \mathrm{a}$ \\
\hline BRSMG Relâmpago & $7.0 \mathrm{a}$ & $12.53 \mathrm{~b}$ & $5.11 \mathrm{a}$ & $31.75 \mathrm{a}$ \\
\hline CMG 1511 & $7.0 \mathrm{a}$ & $10.72 \mathrm{~b}$ & $4.86 \mathrm{a}$ & $39.30 \mathrm{a}$ \\
\hline CMG 2089 & $7.0 \mathrm{a}$ & $12.00 \mathrm{~b}$ & $5.26 \mathrm{a}$ & $34.72 \mathrm{a}$ \\
\hline CMG 1896 & $7.0 \mathrm{a}$ & $10.20 \mathrm{~b}$ & $4.93 \mathrm{a}$ & $39.02 \mathrm{a}$ \\
\hline CMG 2097 & $7.0 \mathrm{a}$ & $12.97 \mathrm{~b}$ & $5.46 \mathrm{a}$ & $37.25 \mathrm{a}$ \\
\hline CMG 2017 & $7.0 \mathrm{a}$ & $10.37 \mathrm{~b}$ & $4.76 \mathrm{a}$ & $39.10 \mathrm{a}$ \\
\hline CMG 1977 & $7.0 \mathrm{a}$ & $10.72 \mathrm{~b}$ & $4.81 \mathrm{a}$ & $34.05 \mathrm{a}$ \\
\hline CMG 1509 & $8.0 \mathrm{a}$ & $11.22 \mathrm{~b}$ & $5.03 \mathrm{a}$ & $40.02 \mathrm{a}$ \\
\hline CMG 1987 & $7.0 \mathrm{a}$ & $12.98 \mathrm{~b}$ & $5.46 \mathrm{a}$ & $34.30 \mathrm{a}$ \\
\hline CV (\%) & 1.03 & 14.31 & 15.98 & 14.15 \\
\hline
\end{tabular}

*Means followed by the same letter at the column do not differ statistically by the Scott-Knott test at $5 \%$ of probability.

but some lines can present quantities that should be considered. In this case, the chlorophyll meter is not useful to indicate the need of nitrogen fertilization, since it does not infer about $\mathrm{N}$ in nitrate form.

Considering all previous characters, the line that showed the best performance was CMG 1967, and the lines that showed the worse performance were CMG 1097-7 and CMG 2173.

The lines showed variability in the quantitative analysis of the enzyme superoxide dismutase (SOD). Some lines had a high activity of SOD with the increasing of days after emergency (DAE), and some lines had the opposite behavior (Figure 1 and Figure 2).

To avoid the accumulation of reactive oxygen species (ROS) and protect the cells of oxidative damages, plants have a defense system antioxidant enzymatic and non-enzymatic that allows detoxification. This defense mechanism requires the action of various antioxidant enzymes acting in synchrony, among which we can highlight the superoxide dismutase. SOD activity has been related to the response of plants to abiotic stresses [24]. Since the rice lines in this study were sown in substrate from an area in no-till system, there is a possibility that this cropping system generates some kind of stress to the plant.

SOD was the first enzyme studied as a mechanism of defense against damages caused by ROS in cells [24]. Under the same denomination, there are others that catalyze the dismutation of free radicals of $\mathrm{O}_{2}$ to $\mathrm{H}_{2} \mathrm{O}_{2}[25]$.

According to Cardoso [26], SOD enzymes show high level of homology between different plant species. However, the number and type of these enzymes varies between plants. Besides that, there are many environmental and biological factors that lead to the accumulation of superoxide in vegetal tissues [27]. Therefore, 


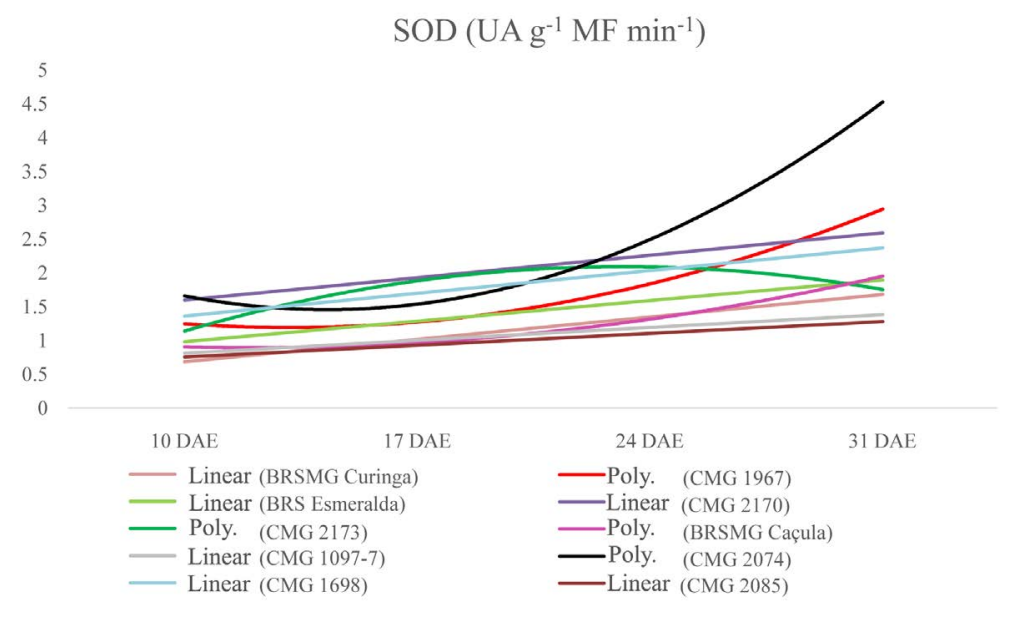

Figure 1. Activity of the enzyme superoxide dismutase (SOD) in leaves of 10 upland rice lines cropped in no-tillage.

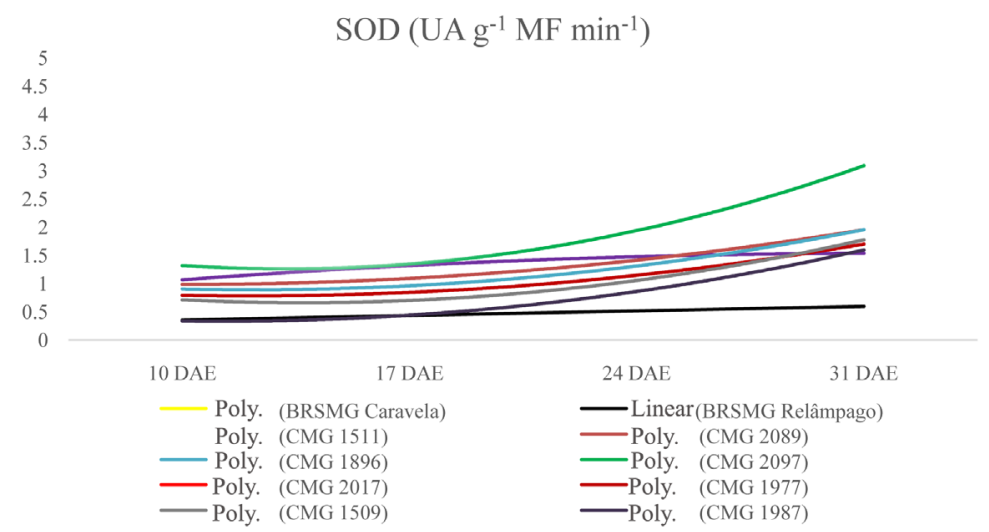

Figure 2. Activity of the enzyme superoxide dismutase (SOD) in leaves of 10 upland rice lines cropped in no-tillage.

plants can induce SOD synthesis as a defense mechanism [28].

The means of character related to the quality of seeds of the 20 lines are shown in Table 2. The lines were statistically different for all characters evaluated.

The germination first count test is based on the affirmation that the genotypes with higher percentage of normal seedling at the twenty-first day after sowing are more vigorous [29]. It is a fast and important test since seedlings emergence speed and uniformity are the most important characters related to the current concept of seeds quality [30].

The lines BRS Esmeralda, BRSMG Caravera, BRSMG Relâmpago, CMG 1511, CMG 1896, CMG 2017 and CMG 1509 had the best performance in the GFC test and, therefore, were considered the most vigorous.

The twenty lines formed three groups with the results of the germination test, discriminating the lines BRSMG Curinga, BRS Esmeralda, CMG 2170, CMG 1097-7, CMG 2074, CMG 2085, BRSMG Caravera, BRSMG Relâmpago, CMG 1511, CMG 2089, CMG 1896, CMG 2097, CMG 2017, CMG 1977, CMG 1509, and CMG 1987 as the ones with best performance, and the lines CMG 1967 and CMG 2173 as the ones with lower quality.

In what regards to the initial stand, the lines formed four groups, discriminating the lines BRS Esmeralda, CMG 2089, CMG 1896 and CMG 1509 as the ones with the best performance. Similar results were found in maize [31] and sorghum [32]. According to Kurachi et al. [33], the initial stand can be highly influenced by environmental factors as distribution of the seeds in the sowing line. Due to its plasticity, rice tends to compensate the smaller number of plants in low densities emerging a large number of tillers per plant [34]. 
Table 2. Percentage of normal seedlings in germination test (GT), germination first count (GFC), initial stand (IS) and emergence $(\mathrm{E})$ in twenty upland rice lines, and their coefficient of variation (CV).

\begin{tabular}{|c|c|c|c|c|}
\hline Lines & GFC (\%) & GT (\%) & IS (\%) & $\mathrm{E}(\%)$ \\
\hline BRSMG Curinga & $66 \mathrm{~b}$ & $92 \mathrm{a}$ & $6 \mathrm{~d}$ & $89 \mathrm{~b}$ \\
\hline CMG 1967 & $48 \mathrm{c}$ & $76 \mathrm{c}$ & $15 \mathrm{c}$ & $75 \mathrm{~b}$ \\
\hline BRS Esmeralda & $85 \mathrm{a}$ & $92 \mathrm{a}$ & $75 \mathrm{a}$ & $91 \mathrm{a}$ \\
\hline CMG 2170 & $72 \mathrm{~b}$ & $88 \mathrm{a}$ & $64 \mathrm{~b}$ & $82 \mathrm{~b}$ \\
\hline CMG 2173 & $69 \mathrm{~b}$ & $77 \mathrm{c}$ & $6 \mathrm{~d}$ & $84 \mathrm{~b}$ \\
\hline BRSMG Caçula & $71 \mathrm{~b}$ & $84 \mathrm{~b}$ & $17 \mathrm{c}$ & $82 \mathrm{~b}$ \\
\hline CMG 1097-7 & $68 \mathrm{~b}$ & $96 a$ & $18 \mathrm{c}$ & $92 \mathrm{a}$ \\
\hline CMG 2074 & $59 \mathrm{c}$ & $92 \mathrm{a}$ & $14 \mathrm{c}$ & $97 \mathrm{a}$ \\
\hline CMG 1698 & $72 \mathrm{~b}$ & $82 \mathrm{~b}$ & $17 \mathrm{c}$ & $93 \mathrm{a}$ \\
\hline CMG 2085 & $68 \mathrm{~b}$ & $90 \mathrm{a}$ & $48 \mathrm{~b}$ & $98 \mathrm{a}$ \\
\hline BRSMG Caravera & $79 \mathrm{a}$ & $96 \mathrm{a}$ & $23 \mathrm{c}$ & $93 \mathrm{a}$ \\
\hline BRSMG Relâmpago & $91 \mathrm{a}$ & $95 \mathrm{a}$ & $21 \mathrm{c}$ & $95 \mathrm{a}$ \\
\hline CMG 1511 & $83 \mathrm{a}$ & $89 a$ & $26 \mathrm{c}$ & $90 \mathrm{a}$ \\
\hline CMG 2089 & $54 \mathrm{c}$ & $90 \mathrm{a}$ & $77 \mathrm{a}$ & $95 \mathrm{a}$ \\
\hline CMG 1896 & $79 \mathrm{a}$ & $90 \mathrm{a}$ & $77 \mathrm{a}$ & $92 \mathrm{a}$ \\
\hline CMG 2097 & $34 \mathrm{~d}$ & $89 \mathrm{a}$ & $59 \mathrm{~b}$ & $93 \mathrm{a}$ \\
\hline CMG 2017 & $79 \mathrm{a}$ & $91 \mathrm{a}$ & $58 \mathrm{~b}$ & $96 a$ \\
\hline CMG 1977 & $75 \mathrm{~b}$ & $91 \mathrm{a}$ & $54 \mathrm{~b}$ & $91 \mathrm{a}$ \\
\hline CMG 1509 & $88 \mathrm{a}$ & $95 \mathrm{a}$ & $74 \mathrm{a}$ & $97 \mathrm{a}$ \\
\hline CMG 1987 & $49 \mathrm{c}$ & $94 \mathrm{a}$ & $60 \mathrm{~b}$ & $91 \mathrm{a}$ \\
\hline CV (\%) & 12.46 & 5.27 & 20.71 & 7.27 \\
\hline
\end{tabular}

Means followed by the same letter at the column do not differ statistically by the Scott-Knott test at $5 \%$ of probability.

The emergency test discriminated the lines BRS Esmeralda, CMG 1097-7, CMG 2074, CMG 1698, CMG 2085, BRSMG Caravera, BRSMG Relâmpago, CMG 1511, CMG 1896, CMG 2097, CMG 2017, CMG 1977, CMG 1509 and CMG 1987 as the ones with high quality.

It is interesting to notice that the lines that showed a gradual accumulation of SOD in their tissues (lines CMG 2074, CMG 1967, CMG 2017, BRSMG Caravera and CMG 2097), also showed high quality in their seeds. These results suggest an association between the content of SOD in vegetal tissues and the tolerance to abiotic stress. Considering all previous tests simultaneously, the lines with high seeds quality were BRS Esmeralda, CMG 1896 and CMG 1509.

The expression of the alpha-amylase enzyme varied between lines but did not show correlation with the seeds quality (Figure 3).

Studying the expression of alpha-amylase in seeds of maize lines, Oliveira et al. [35] discussed that besides the genes that control the content of amylase in seeds, many other genes may be related to the genetic control of seeds quality, as the genes that participate of the respiration process. This fact may also explain why lines with high quality showed low expression of alpha-amylase in this study.

\section{Conclusions}

The lines CMG 2074, CMG 1967, CMG 2017, BRSMG Caravera and CMG 2097 showed higher SOD content 


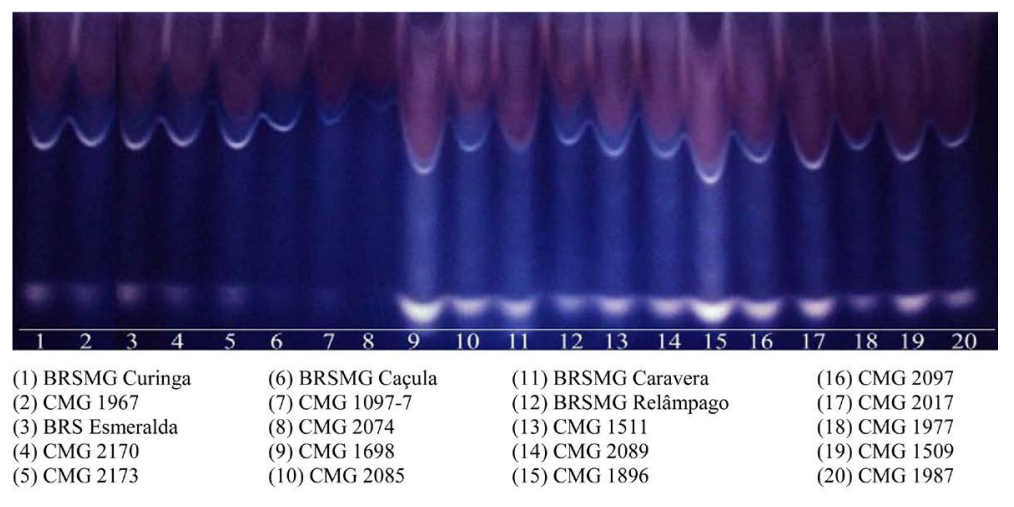

Figure 3. Alpha-amylase expression in seeds of the 20 upland rice lines.

in the enzymatic analyses, and consequently higher tolerance to abiotic stress.

Considering the evaluation of agronomic traits, the line CMG 1967 showed the best performance in no-tillage system and, therefore, should receive higher attention in Upland Rice Breeding Programs.

\section{Acknowledgements}

The Brazilian Development Agency CAPES (Coordenação de Aperfeiçoamento de Pessoal de Nível Superior) supported this research; process CAPES/PNPD 23038007035/2011-17 (2801/2011).

\section{References}

[1] Walter, M. and Avila, L.A. (2008) Arroz: Composição e características nutricionais. Ciência Rural, 38, $1184-1192$. http://dx.doi.org/10.1590/S0103-84782008000400049

[2] CONAB (2015) Campanha Nacional de Abastecimento. http://www.conab.gov.br

[3] Crusciol, C.A.C., Soratto, R.P., Arf, O. and Mateus, G.P. (2006) Yield of Upland Rice Cultivars in Rainfed and Sprinkler-Irrigated Systems in the Cerrado Region of Brazil. Australian Journal of Experimental Agriculture, 46, 1515-1520. http://dx.doi.org/10.1071/EA04035

[4] Andrioli, I., Beutler, A.N., Centurion, J.F., Andrioli, F.F. and Coutinho, E.L.M. (2008) Corn in No-Till System with Nitrogen Fertilization and Soil Cover Crops Preceding. Revista Brasileira de Ciência do Solo, 32, 1691-1698. http://dx.doi.org/10.1590/S0100-06832008000400034

[5] Kluthcouski, J., Fancelli, A.L., Dourado Neto, D., Ribeiro, C.M. and Ferraro, L.A. (2000) Manejo do solo e o rendimento de soja, milho, feijão e arroz em plantio direto. Scientia Agricola, 57, 97-104. http://dx.doi.org/10.1590/S0103-90162000000100016

[6] Beauchamp, C. and Fridovich, I. (1971) Superoxide Dismutase: Improved Assays and an Assay Applicable to Acrylamide Gels. Analytical Biochemistry, 44, 276-287. http://dx.doi.org/10.1016/0003-2697(71)90370-8

[7] Brasil (2009) Ministério da Agricultura, Pecuária e Abastecimento. Regras para análise de sementes, Brasília.

[8] Ferreira, D.F. (2011) Sisvar: A Computer Statistical Analysis System. Ciência e Agrotecnologia, 35, 1039-1042.

[9] Scott, A. and Knott, M. (1974) Cluster-Analysis Method for Grouping Means in Analysis of Variance. Biometrics, 30, 507-512. http://dx.doi.org/10.2307/2529204

[10] Queiroz, L.A.F., Von Pinho, E.V.R., Oliveira, J.A., Ferreira, V.F., Carvalho, B.O. and Bueno, A.C.R. (2011) Época de colheita e secagem na qualidade de sementes de pimenta Habanero Yellow. Revista Brasileira de Sementes, 33, 472481. http://dx.doi.org/10.1590/S0101-31222011000300010

[11] Strassburger, A.S., Peil, R.M.N., Schwengber, J.E., Medeiros, C.A.B., Martins, D.S. and Silva, J.B. (2010) Crescimento e produtividade de cultivares de morangueiro de "dia neutron" em diferentes densidades de plantio em sistema de cultivo orgânico. Bragantia, 69, 623-630. http://dx.doi.org/10.1590/S0006-87052010000300014

[12] Geraldo, J., Oliveira, L.D., Pereira, M.B. and Pimentel, C. (2002) Fenologia e produção de massa seca e de grãos em cultivares de milheto-pérola. Pesquisa Agropecuária Brasileira, 37, 2093-2098. http://dx.doi.org/10.1590/S0100-204X2002000900009

[13] Mauad, M., Grassi Filho, H., Crusciol, C.A.C. and Correa, J.C. (2003) Teores de silício no solo e na planta de arroz de terras altas com diferentes doses de adubação silicatada e nitrogenada. Revista Brasileira de Ciência do Solo, 27, 867- 
873. http://dx.doi.org/10.1590/S0100-06832003000500011

[14] Ramos, L.A., Korndorfer, G.H. and Nolla, A. (2008) Acúmulo de silício em plantas de arroz do ecossistema de várzea submetido à aplicação de diferentes fontes. Bragantia, 67, 751-757. http://dx.doi.org/10.1590/S0006-87052008000300025

[15] Ludwig, J., Moura, A.B., Santos, A.S. and Ribeiro, A.S. (2009) Microbiolização de sementes para o controle da mancha-parda e da escaldadura em arroz irrigado. Tropical Plant Pathology, 34, 322-328. http://dx.doi.org/10.1590/S1982-56762009000500005

[16] Zietemann, C. and Roberto, R.F. (2007) Efeito de diferentes substratos e épocas de coleta no enraizamento de estacas herbáceas de goiabeira, cvs. Paluma e Século XXI. Revista Brasileira de Fruticultura, 29, 31-36. http://dx.doi.org/10.1590/S0100-29452007000100009

[17] Oliveira Jr., R.S., Constantin, J., Costa, J.M., Cavalieri, S.D., Arantes, J.G.Z., Alonso, D.G., Roso, A.C. and Biffe, D.F. (2006) Interação entre sistemas de manejo e controle de plantas daninhas em pós-emergência afetando o desenvolvimento e a produtividade da soja. Planta Daninha, 24, 721-732. http://dx.doi.org/10.1590/S0100-83582006000400013

[18] Hofs, A., Schuch, L.O.B., Peske, S.T. and Barros, A.C.S.A. (2004) Emergência e crescimento de plântulas de arroz em resposta á qualidade fisiológica de sementes. Revista Brasileira de Sementes, 26, 92-97. http://dx.doi.org/10.1590/S0101-31222004000100014

[19] Correia, N.M. and Durigan, J.C. (2004) Emergência de plantas daninhas em solo coberto com palha de cana-de-açúcar. Planta Daninha, 22, 11-17. http://dx.doi.org/10.1590/S0100-83582004000100002

[20] Godoy, L.J.G., Santos, T.S., Villas Boas, R.L. and Leite Jr., J.B. (2008) Índice relative de clorofila e estado nutricional em nitrogênio durante o ciclo do cafeeiro fertirrigado. Revista Brasileira de Ciência do Solo, 32, 217-226. http://dx.doi.org/10.1590/S0100-06832008000100021

[21] Lopes, E.C.P., Moraes, A., Sandini, I.E., Kaminski, T.H., Basi, S. and Pacentchuck, F. (2012) Relação da Leitura do Clorofilômetro com Teores de Nitrogênio na Folha de Milho em Sistema de Integração Lavoura-Pecuária. Congresso Nacional de Milho e Sorgo, Águas de Lindóia, 26-30 August 2012.

[22] Argenta, G. (2001) Monitoramento do nível de nitrogênio na planta como indicador da adubação nitrogenada em milho. Thesis (PhD in Fitotecnia), Programa de Pós-graduação em Fitotecnia, Faculdade de Agronomia, Universidade Federal do Rio Grande do Sul, Porto Alegre.

[23] Takebe, M. and Yoneyama, T. (1989) Measurement of Leaf Color Scores and Its Implication to Nitrogen Nutrition of Rice Plants. JARQ, 23, 86-93.

[24] Gratão, P.L., Polle, A., Lea, P.J. and Azevedo, R.A. (2005) Making the Life of Heavy Metal-Stressed Plants a Little Easier. Functional Plant Biology, 32, 481-494. http://dx.doi.org/10.1071/FP05016

[25] Alscher, R.G., Erturk, N. and Heath, L.S. (2002) Role of Superoxide Dismutases (SODs) in Controlling Oxidative Stress in Plants. Journal of Experimental Botany, 53, 1331-1341. http://dx.doi.org/10.1093/jexbot/53.372.1331

[26] Cardoso, P.F. (2000) Resposta de linhagens de arroz à exposição ao cádmio. Dissertation (Master), Escola superior de Agricultura "Luiz de Queiroz", Universidade de São Paulo.

[27] Scandalios, J.G. (1993) Oxygen Stress and Superoxide Dismutases. Plant Physiology, 101, 7-12.

[28] Kliebenstein, D.J., Monde, R.A. and Last, R.L. (1998) Superoxide Dismutase in Arobidopsis: An Eclectic Enzyme Family with Disparate Regulation and Protein Localization. Plant Physiology, 118, 637-650. http://dx.doi.org/10.1104/pp.118.2.637

[29] Krzyzanowki, F.C. and Vieira, R.D. (1999) Deterioração controlada. In: Krzyzanowki, F.C., Vieira, R.D. and França Neto, J.B., Eds., Vigor de sementes: Conceitos etestes, ABRATES, Londrina, 61-68.

[30] Willyder, L.R.P. (2010) Testes de vigor em sementes de milho. Dissertação (Mestrado em Fitotecnia), Universidade Estadual Paulista, Faculdade de Ciências Agrárias e Veterinárias, Jaboticabal.

[31] Andreoli, C., Aandrade, V.R., Zamora, S.A. and Gordon, M. (2002) Influência da germinação da semente e da densidade de semeadura no estabelecimento do estande e na produtividade de milho. Revista Brasileira de Sementes, 24, 1-5. http://dx.doi.org/10.1590/S0101-31222002000100001

[32] Carvalho, L.F., Medeiros Filho, S., Rossetti, A.G. and Teofilo, E.M. (2000) Condicionamento osmótico em sementes de sorgo. Revista Brasileira de Sementes, 22, 185-192. http://dx.doi.org/10.17801/0101-3122/rbs.v22n1p185-192

[33] Kurachi, S.A.H., Costa, J.A.S., Bernardi, J.A., Coelho, J.L.D. and Silveira, G.M. (1989) Avaliação tecnológica de semeadoras e/ou adubadoras: Tratamento de dados de ensaios e regularidade de distribuição longitudinal de sementes. Bragantia, 48, 249-262. http://dx.doi.org/10.1590/S0006-87051989000200011

[34] Loomis, R.S. and Connor, D.J. (1992) Crop Ecology: Productivity and Management in Agricultural Systems. Cambridge University Press, Cambridge, 32-59. http://dx.doi.org/10.1017/cbo9781139170161 
[35] Oliveira, G.E., Von Pinho, R.G., Andrade, T., Von Pinho, E.V.R., Santos, C.D. and Veiga, A.D. (2013) Physiological Quality and Amylase Enzyme Expression in Maize Seeds. Ciência e Agrotecnologia, 37, 40-48.

http://dx.doi.org/10.1590/S1413-70542013000100005 